\title{
Pengaruh pertumbuhan ekonomi, inflasi dan tingkat pengangguran terbuka terhadap jumlah penduduk miskin di Provinsi Jambi
}

\author{
*Arif Rahman; Drs. H. Purwaka. HP, M.Si; Dr. M. Syafri, M.Si
}

Prodi Ekonomi Pembangunan, Fakultas Ekonomi dan Bisnis, Universitas Jambi

*E-mail korespondensi: makro_arifrahman@yahoo.com

\begin{abstract}
Study aims to: 1) To find out the development of economic growth, inflation and the level of open unemployment in Jambi Province; 2) To analyze the influence of economic growth, inflation and the open unemployment rate on the number of poor people in Jambi Province. This research uses secondary data for the period 2001-2016. The method used in analyzing the data is by using multiple regression analysis. The results of this study indicate that: 1) The poor population in Jambi Province from 2001-2016 has decreased, where the number of poor people in Jambi Province has decreased by 0.46 percent. Economic growth in Jambi Province on the basis of constant prices from 2001-2016 experienced an average fluctuation of 6.23 percent per year. During the period of 2001-2016 the inflation rate in Jambi Province was an average of 12.25 percent. The highest number of unemployed occurred in 2005, amounting to 133,964 people and then in 2016 a decrease of 67,671 people; 2) Every increase in economic growth in Jambi Province is 1 percent, the poverty rate of the population in Jambi Province will decrease by 0.140 percent. The results of this test indicate that economic growth has a negative impact on the number of poverty in Jambi Province. Every increase in the inflation rate by 1 percent, the poverty rate will increase by 0.002 percent and every increase in the unemployment rate in Jambi Province by 1 percent, the poverty rate of the population in Jambi Province will increase by 0.052 percent. Together economic growth, inflation and unemployment have a positive and significant effect on the poverty rate of the population in Jambi Province during the period 20012016. Variation in ups and downs the poverty rate of the population in Jambi Province is able to explain economic growth, inflation and unemployment by 35.2 percent, while the remaining 64.8 percent is explained by other variables not included in this research model.
\end{abstract}

\begin{abstract}
Abstrak
Penelitian ini bertujuan untuk: 1) Untuk mengetahui perkembangan pertumbuhan ekonomi, inflasi dan tingkat pengangguran terbuka di Provinsi Jambi; 2) Untuk menganalisis besar pengaruh pertumbuhan ekonomi, inflasi dan tingkat pengangguran terbuka terhadap jumlah penduduk miskin di Provinsi Jambi. Penelitian ini dengan menggunakan data sekunder periode 2001-2016. Metode yang digunakan dalam menganalisis data adalah dengan menggunakan analisis regresi berganda. Hasil penelitian ini menunjukkan bahwa: 1) Penduduk miskin di Provinsi Jambi dari tahun 2001-2016 mengalami penurunan, dimana jumlah penduduk miskin di Provinsi Jambi mengalami penurunan sebesar 0,46 persen. Pertumbuhan ekonomi di Provinsi Jambi atas dasar harga konstan dari tahun 2001-2016 mengalami fluktuasi rata-rata 6,23 persen pertahun. Selama periode 2001-2016 tingkat inflasi di Provinsi Jambi secara
\end{abstract}


rata-rata adalah sebesar 12,25 persen. Jumlah pengangguran tertinggi terjadi pada tahun 2005 yaitu sebesar 133,964 jiwa dan kemudian pada tahun 2016 penurunan sebesar 67,671 jiwa; 2) Setiap kenaikan pertumbuhan ekonomi di Provinsi Jambi sebesar 1 persen maka angka kemiskinan penduduk di Provinsi Jambi akan mengalami penurunan sebesar 0,140 persen. Hasil pengujian ini menunjukkan bahwa pertumbuhan ekonomi berdampak negatif terhadap angka kemskinan di Provinsi Jambi. Setiap terjadi peningkatan angka angka inflasi sebesar 1 persen maka angka kemiskinan akan mengalami peningkatan sebesar 0,002 persen dan setiap terjadi peningkatan angka pengangguran di Provinsi Jambi sebesar 1 persen maka angka kemiskinan penduduk di Provinsi Jambi akan mengalami peningkatan sebesar 0,052 persen. Secara bersamasama pertumbuhan ekonomi, inflasi dan pengangguran berpengaruh positif dan signifikan terhadap angka kemiskinan penduduk di Provinsi Jambi selama periode 2001-2016. Variasi naik turunnya angka kemiskinan penduduk di Provinsi Jambi mampu dijelaskan pertumbuhan ekonomi, inflasi dan pengangguran sebesar 35,2 persen, sementara sisanya sebesar 64,8 persen dijelaskan oleh variabel lainnya yang tidak dimasukkan dalam model penelitian ini.

\section{PENDAHULUAN}

Masalah kemiskinan dapat ditinjau dari berbagai sudut pandang. Secara umum, kemiskinan adalah ketidakmampuan seseorang untuk memenuhi kebutuhan dasar standar atas setiap aspek kehidupan. Selama lima tahun terakhir jumlah penduduk miskin di Provinsi Jambi mengalami peningkatan yang cukup signifikan, yaitu dari 270.200 jiwa tahun 2012 meningkat menjadi 299.100 jiwa pada tahun 2016 atau mengalami peningkatan rata-rata sebesar 2,13 persen per tahun.

Program penanggulangan angka kemiskinan mutlak diperlukan agar semua kebijakan pemerintah dapat lebih terarah dan tepat sasaran. Untuk menyusun program penanggulangan kemiskinsn maka perlu dilakukan kajian yang mendalam tentang faktor-faktor yang bereran penting dalam mengurangi jumlah penduduk miskin. Faktorfaktor yang mempengaruhi tingkat kemiskinan adalah pertumbuhan ekonomi, pengangguran dan inflasi. Pertumbuhan ekonomi yang tinggi dan disertai pemerataan hasil pertumbuhan keseluruh sektor usaha sangat dibutuhkan dalam upaya menurunkan tingkat kemiskinan. Salah satu unsur yang menentukan kemakmuran suatu masyarakat adalah tingkat pendapatan. Pendapatan mencapai maksimum apabila kondisi tingkat tenaga kerja penuh (Full Employment) dapat terwujud. Pengangguran akan menimbulkan efek mengurangi pendapatan, dan akan mengurangi tingkat kemakmuran. Semakin turun tingkat kemakmuran akan menimbulkan masalah lain yaitu kemiskinan (Maipita, 2014).

Provinsi Jambi sebagai salah satu daerah di Indonesia juga sedang giat-giatnya melaksanakan pembangunan di semua sektor kehidupan dalam rangka meningkatkan derajat kehidupan masyarakat. Di samping itu pertumbuhan ekonomi alat untuk mengetahui perkembangan dan struktur ekonomi suatu wilayah dan diyakini masih merupakan indikator penting dalam menentukan arah pembangunan. Pertumbuhan ekonomi yang positif mencerminkan terjadinya peningkatan aktivitas ekonomi masyarakat di semua sektor ekonomi. Peningkatan aktivitas ini sudah barang tentu akan meningkatkan pendapatan masyarakat, peningkatan pendapatan masyarakat diharapkan dapat mendorong peningkatan kesejahteraan masyarakat dan mengurangi angka kemiskinan. Secara kuantitatif peninkgatan pertumbuhan ekonomi akan mengurangi penduduk miskin 
Faktor yang menyebabkan tingkat kemiskinan salah satunya yaitu pengangguran. Pengangguran merupakan salah satu masalah utama yang selalu dihadapi setiap negara dimanapun. Jika berbicara tentang masalah pengangguran, berarti tidak hanya berbicara tentang masalah sosial tetapi juga berbicara tentang masalah ekonomi, karena pengangguran selain menyebaban masalah sosial juga memberikan pengaruh terhadap pertumbuhan ekonomi suatu negara khususnya negara yang sedang berkembang seperti Indonesia. Pengangguran merupkana beban bagi penduduk produktif karena mereka turut membiayai kebutuhan para pengangguran tersebut.

Menurut Badan Pusat Statistik (BPS) dalam indikator ketenagakerjaan, pengangguran merupakan penduduk usia kerja yang tidak bekerja tetapi sedang mencari pekerjaan atau sedang mempersiapkan suatu usaha baru atau penduduk yang tidak mencari pekerjaan karena sudah diterima bekerja tetapi belum mulai bekerja. Pada tahun 2001 jumlah pengangguran terbuka di Provinsi Jambi adalah sebesar 60.240 jiwa, sementara hingga tahun 2016 angka pengangguran di Provinsi Jambi mencapai 67.671 jiwa atau mengalami peningkatan rata-rata sebesar 0,82 persen per tahun (BPS Provinsi Jambi, 2017).

Meningkatnya angka pengangguran disebabkan karena ketidakseimbangan pertumbuhan angkatan kerja dan penciptaan kesempatan kerja atau penyerapan lapangan pekerjaan yang ada. Adanya kesenjangan antara pertambahan angkatan kerja dan lapangan kerja yang tersedia berdampak terhadap urbanisasi baik secara spasial antara desa-kota maupun secara sektoral. Hal ini sejalan dengan pernyataan Todaro (2003) yang menjelaskan bahwa terjadinya perpindahan penduduk disebabkan oleh tingginya upah atau pendapatan yang diperoleh di daerah tujuan. Kesenjangan upah/pendapatan yang besar antara desa atau daerah dan kota mendorong penduduk desa atau daerah untuk datang dan mencari pekerjaan di kota. Banyaknya arus urbanisasi ini akan menimbulkan masalah dan menjadi beban bagi daerah perkotaan akibatnya akan timbul masalah-masalah sosial di Kota.

Faktor lain yang sangat penting untuk diperhatikan adalah inflasi. Inflasi adalah kenaikan harga-harga yang terjadi secara terus menerus dalam jangka waktu tertentu. Kenaikan harga-harga jelas akan menyebabkan kemampuan daya beli masyarakat akan semakin rendah, sehingga secara langsung akan memberikan dampak semakin meningkatnya jumlah penduduk miskin. Selama tahun 2001-2016 laju inflasi di Provinsi Jambi menunjukkan kecenderungan yang berfluktuasi dai tahun ke tahun, secara umum inflasi di Provinsi Jambi masih di bawah angka 10\%, kecuali pada tahun 2008 sebesar, 14,52\%, tahun 2010 sebesar 11,21\%. Angka inflasi yang terlalu besar lebih dari 2 digit sudah barang tentu akan lebih berdampak buruk terhadap penurunan daya beli masyarakat. Hal ini akan berdampak terhadap meningkatnya jumlah penduduk miskin.

Masih relatif tingginya tingkat kemiskinan di Provinsi jambi merupakan masalah pokok yang diangkat dalam penelitian ini. Untuk mengatasi masalah kemiskinan tersebut sebelumnya perlu adanya analisis faktor-faktor apa saja yang mempengaruhi kemiskinan di Provinsi Jambi sehingga nantinya dapat dirumuskan strategi dan kebijakan yang tepat dalam menguranginya. Pertumbuhan ekonomi yang cukup tinggi, tingkat pengangguran yang cukup besar dan inflasiyang terjadi setiap tahun Di duga merupakan faktor yang mempengaruhi masih tingginya angka kemiskinan di Provinsi Jambi. lebih lanjut penelitian ini akan membahas bagaimana pengaruh pertumbuhan ekonomi, tingkat pengangguran dan inflasi terhadap kemiskinan di Provinsi Jambi dan dituangkan dalam sebuah penelitian yang diberi judul "Pengaruh Pertumbuhan Ekonomi, Inflasi dan Tingkat Pengangguran Terbuka Terhadap Jumlah 


\section{Penduduk Miskin Di Provinsi Jambi”.}

Berdasarkan fakta dan analisis di atas, maka dapat dirumuskan masalah pokok dari penelitian ini adalah:

1. Bagaimanakah perkembangan pertumbuhan ekonomi, inflasi dan tingkat pengangguran terbuka di Provinsi Jambi?

2. Bagaimana pengaruh pertumbuhan ekonomi, inflasi tingkat pengangguran terbuka terhadap jumlah penduduk miskin di Provinsi Jambi?

\section{METODE PENELITIAN}

Analisis deskriftif ini merupakan suatu analisis yang menguraikan atau mendeskripsikan data hasil penelitian tanpa melakukan pengujian. Alat analisis digunakan untuk menjawab permasalahan pertama, yaitu untuk mengetahui pertumbuhan ekonomi, inflasi dan tingkat pengangguran di Provinsi Jambi. Untuk menjawab permasalahan ke dua, yaitu untuk menganalisis pengaruh pertumbuhan ekonomi, inflasi, dan tingkat pengangguran terhadap jumlah penduduk miskin di Provinsi Jambi, maka digunakan analisis statistik. Dalam hal ini, teknik statistik menggunakan alat bantu program SPSS versi 20.

Adapun persamaan regresi yang digunakan adalah sebagi berikut: (Gujarati, 2005: 201).

$$
\mathrm{Y}=\mathrm{a}+\mathrm{b}_{1} \mathrm{X}_{1}+\mathrm{b}_{2} \mathrm{X}_{2}+\mathrm{b}_{3} \mathrm{X}_{3}+\mathrm{e}
$$

Kemudian ditransformasikan dalam model log dengan rumus:

$$
\begin{array}{ll} 
& \log \mathrm{Y}=\mathrm{a}+\mathrm{b}_{1} \mathrm{X}_{1}+\mathrm{b}_{2} \mathrm{X}_{2}+\mathrm{b}_{3} \log \mathrm{X}_{3}+\mathrm{e} \\
\text { Dimana: } & \\
\mathrm{Y} & =\text { Jumlah Penduduk Miskin di Provinsi Jambi } \\
\mathrm{a} & =\text { Konstanta } \\
\mathrm{b} & =\text { Intercept (Nilai Aminimum) } \\
\mathrm{X}_{1} & =\text { Pertumbuhan Ekonomi } \\
\mathrm{X}_{2} & =\text { Inflasi } \\
\mathrm{X}_{3} & =\text { Jumlah Pengangguran } \\
\mathrm{e} & =\text { Kesalahan Penganggu (disturbance error) }
\end{array}
$$

\section{HASIL DAN PEMBAHASAN}

Selama kurun waktu 2001-2016 jumlah penduduk miskin di Provinsi Jambi menunjukkan kecenderungan yang menurun, sebagaimana tergambar pada tabel berikut:

Tabel 1. Perkembangan Jumlah Penduduk Misikin Provinsi Jambi periode 2001-2016

\begin{tabular}{|c|c|c|c|c|}
\hline Tahun & $\begin{array}{c}\text { Penduduk Miskin } \\
\text { (Jiwa) }\end{array}$ & $\begin{array}{c}\text { Perkembangan } \\
(\%)\end{array}$ & $\begin{array}{c}\text { Jumlah } \\
\text { Penduduk } \\
\text { Provinsi Jambi } \\
\text { (Jiwa) }\end{array}$ & $\begin{array}{c}\text { Rasio } \\
\text { Penduduk } \\
\text { Miskin (\%) }\end{array}$ \\
\hline 2001 & 325.500 & & 2.439 .873 & 13,34 \\
\hline 2002 & 326.900 & 0,43 & 2.484 .027 & 13,16 \\
\hline 2003 & 327.300 & 0,12 & 2.568 .598 & 12,74 \\
\hline 2004 & 325.100 & $(0,67)$ & 2.619 .553 & 12,41 \\
\hline 2005 & 317.800 & $(2,25)$ & 2.635 .968 & 12,06 \\
\hline 2006 & 304.600 & $(4,15)$ & 2.683 .099 & 11,35 \\
\hline 2007 & 281.900 & $(7,45)$ & 2.742 .196 & 10,28 \\
\hline
\end{tabular}




\begin{tabular}{|c|c|c|c|c|}
\hline 2008 & 261.200 & $(7,34)$ & 2.788 .269 & 9,37 \\
\hline 2009 & 245.000 & $(6,20)$ & 2.834 .164 & 8,64 \\
\hline 2010 & 260.445 & 6,30 & 3.092 .265 & 8,42 \\
\hline 2011 & 251.790 & $(3,32)$ & 3.169 .814 & 7,94 \\
\hline 2012 & 270.200 & 7,31 & 3.242 .814 & 8,33 \\
\hline 2013 & 277.700 & 2,78 & 3.317 .034 & 8,37 \\
\hline 2014 & 281.750 & 1,46 & 3.344 .421 & 8,42 \\
\hline 2015 & 292.000 & 3,64 & 3.402 .052 & 8,58 \\
\hline 2016 & 299.100 & 2,43 & 3.458 .926 & 8,65 \\
\hline \multicolumn{2}{|c|}{ Rata-Rata } & $(0.46)$ & & 10.13 \\
\hline
\end{tabular}

Sumber: BPS Provinsi Jambi, 2017

Berdasarkan Tabel 1, menunjukan bahwa jumlah penduduk miskin di Provinsi Jambi dari tahun 2001-2016 mengalami penurunan, dimana jumlah penduduk miskin di Provinsi Jambi mengalami penurunan sebesar $0,46 \%$. Penurunan jumlah penduduk miskin tertinggi terjadi pada tahun 2007, yaitu sebesar 7,45\%. Penurunan ini kenaikan aktivitas ekonomi yang terlihat dari peningkatan PDRB Provinsi Jambi. Peningkatan aktivitas ekonomi disebabkan berbagai program pembangunan yang dilakukan pemerintah, baik program pengentasan kemiskinan maupun pembangunan infrastruktur.

Penurunan jumlah penduduk miskin selama periode penelitian tidak selamanya terjadi, peningkatan jumlah penduduk miskin juga terjadi pada tahun 2012, yaitu sebesar 7,31\%. Peningkatan jumlah penduduk miskin ini tidak terlepas pula dari kondisi perekonomian nasional dan daerah yang disebabkan imbas kenaikan harga BBM yang menyebabkan kemampuan daya beli masyarakat rendah, karena kenaikan BBM mendorong peningkatan harga-harga.

Penurunan jumlah penduduk miskin dapat juga dilihat dari rasio jumlah penduduk miskin. Sejak 2008 penduduk miskin di Provinsi Jambi selalu di bawah 2 digit, bahkan rasionya menunjukkan kecenderungan yang menurun.

\section{Pertumbuhan Ekonomi}

Pertumbuhan ekonomi menunjukan sejauh mana aktivitas perekonomian akan menghasilkan tambahan pendapatan masyarakat pada suatu periode tertentu, karena pada dasarnya aktivitas perekonomian adalah suatu proses penggunaan faktor-faktor produksi untuk menghasilkan output, maka proses ini pada gilirannya akan menghasilkan suatu aliran balas jasa terhadap faktor produksi yang dimiliki oleh masyarakat sebagai pemilik faktor produksi juga akan turut meningkat. Berikut gambaran yang lebih jelas mengenai pertumbuhan ekonomi Provinsi Jambi selama periode 2001-2016 dapat dilihat pada Tabel 2:

Tabel 2. Pertumbuhan Ekonomi Provinsi Jambi Periode 2001-2016

\begin{tabular}{|c|c|c|}
\hline Tahun & $\begin{array}{c}\text { PDRB ADHK 2010 } \\
\text { (Rp. Juta) }\end{array}$ & $\begin{array}{c}\text { Pertumbuhan } \\
\text { Ekonomi (\%) }\end{array}$ \\
\hline 2001 & 53.204 .847 & - \\
\hline 2002 & $56,032,888$ & 5,32 \\
\hline 2003 & 58.832 .903 & 5,00 \\
\hline 2004 & 61.999 .859 & 5,38 \\
\hline 2005 & 65.290 .593 & 5,31 \\
\hline 2006 & 69.137 .899 & 5,89 \\
\hline 2007 & 73.853 .861 & 6,82 \\
\hline
\end{tabular}




\begin{tabular}{|c|c|c|}
\hline 2008 & 79.139 .001 & 7,16 \\
\hline 2009 & 84.186 .000 & 6,38 \\
\hline 2010 & 90.618 .411 & 7,64 \\
\hline 2011 & 97.740 .874 & 7,86 \\
\hline 2012 & 104.615 .082 & 7,03 \\
\hline 2013 & 111.766 .131 & 6,84 \\
\hline 2014 & 119.991 .444 & 7,36 \\
\hline 2015 & 125.036 .398 & 4,20 \\
\hline 2016 & 130.499 .600 & 4,37 \\
\hline Rata-rata & & $\mathbf{6 , 2 3}$ \\
\hline
\end{tabular}

Sumber: BPS Provinsi Jambi, 2017

Berdasarkan Tabel 2, menunjukan bahwa pertumbuhan ekonomi di Provinsi Jambi atas dasar harga konstan dari tahun 2001-2016 mengalami fluktuasi rata-rata 6,23 persen pertahun. Pertumbuhan ekonomi di Provinsi Jambi pada tahun 2002 sebesar 5,00 persen, dan meningkat pada tahun 2006 sebesar 5,32 persen, mengalami peningkatan pada tahun 2005 menjadi 5,31 persen, dan pada tahun 2016 pertumbuhan ekonomi mengalami peningkatan kembali sebesar 4,37 persen, akan tetapi peningkatan pertumbuhan ekonomi di Provinsi Jambi lebih rendah dari tahun sebelumnya. Pertumbuhan ekonomi yang tinggi merupakan indikasi bahwa adanya peranan sektor ekonomi yang tinggi terhadap pembentukan PDRB di Provinsi Jambi.

Dalam teori ekonomi makro, dari sisi pengeluaran, pendapatan regional bruto adalah penjumlahan dari berbagai variabel termasuk di dalamnya adalah investasi. Ada beberapa hal yang sebenarnya berpengaruh dalam soal investasi ini. Investasi sendiri dipengaruhi oleh investasi asing dan domestik. Investasi yang terjadi di daerah terdiri dari investasi pemerintah dan investasi swasta. Investasi dari sektor pemerintah dapat berasal dari dalam belanja modal. Investasi pemerintah dilakukan guna menyediakan barang publik. Selain itu, aspek stabilitas politik dan keamanan, meskipun tidak mencukupi merupakan prasyarat yang sangat penting bagi keberlangsungan investasi, terutama investasi asing.

Inflasi

Perkembangan tingkat inflasi di Provinsi Jambi pada dasarnya menunjukkan kecenderungan yang berfluktuasi dan tergantung dengan kondisi perekonomian, termasuk di dalamnya adalah perubahan perekonomian global, hal ini menggambarkan bahwa globalisasi ekonomi telah mendorong keterkaitan perekonomian dengan wilayah atau dampak global perekonomian dunia, perkembangan yang terjadi pada suatu wilayah atau negara akan memberikan dampak terhadap perkembangan negara lain, dampak tersebut dapat berupa krisis ekonomi maupun perkembangan ekonomi yang semakin pesat. Selama periode 2001-2016 inflasi di Provinsi Jambi menunjukkan kecenderungan yang berfluktuasi.

Untuk lebih jelasnya perkembangan inflasi selama periode penelitian dapat dilihat pada tabel berikut: 
Tabel 3. Laju Inflasi di Provinsi Jambi periode 2001-2016

\begin{tabular}{|c|c|}
\hline Tahun & Laju Inflasi $\mathbf{( \% )}$ \\
\hline 2001 & 17,26 \\
2002 & 16,95 \\
2003 & 13,92 \\
2005 & 10,20 \\
2006 & 13,44 \\
2007 & 12,64 \\
2008 & 14,52 \\
2009 & 9,40 \\
2010 & 12,50 \\
2011 & 10,10 \\
2012 & 12,60 \\
2013 & 3,79 \\
2014 & 10,2 \\
2015 & 16,55 \\
2016 & 10,66 \\
\hline Rata-rata & 11,32 \\
\hline
\end{tabular}

Sumber: BPS Provinsi Jambi, 2017

Berdasarkan Tabel 3, tergambar bahwa inflasi tertinggi di Provinsi Jambi selama periode 2001-2016 adalah sebesar 17,26 persen yang terjadi pada tahun 2011, tingginya inflasi pada tahun 2011 lebih disebabkan karena terjadinya kenaikan harga di dalam negeri sehingga memicu kenaikan harga-harga dan biaya transportasi. Sejak krisis ekonom tahun 1997-1999 maka pemulihan ekonomi masih terus terjadi hingga tahun 2001, sehingga sangatlah waja bila inflasi masih tetap tinggi pasca krisis ekonomi yang melanda bangsa Indonesia.

Inflasi terendah di Provinsi Jambi selama kurun waktu 2001-2016 terjadi pada tahun 2012, yaitu sebesar 3,79 persen. Rendahnya laju inflasi pada tahun ini disebabkan tidak terjadinya gejolak ekonomi baik secara regional maupun internasional yang dapat mengganggu stabiitas ekonomi meskipun pada tahun 2010 terjadi kenaikan harga minyak. Selama periode 2001-2016 tingkat inflasi di Provinsi Jambi secara rata-rata adalah sebesar 12,25 persen. Angka ini sudah cukup tinggi di atas satu digit, inflasi yang tinggi dapat menyebabkan stanganasinya pertumbuhan ekonomi bagi Provinsi Jambi, di samping itu juga inflasi yang tinggi akan menyebabkan kemampuan daya beli masyarakat mengalami penurunan dan menjadi salah satu penyebab semakin meningkatnya angka kemiskinan.

\section{Jumlah Pengangguran Terbuka di Provinsi Jambi}

Masalah pengangguran merupakan masalah klasik yang hampir terjadi dimanapun wilayah atau daerah. Masalah pengangguran adalah masalah ekonomi jangka panjang yang harus dipecahkan secara berkesinambungan dari waktu ke waktu dengan melibatkan lintas sektoral, sehingga dalam penanganannya dapat terjaga dengan baik. Ketidakmampuan mengatasi masalah pengangguran akan menyebabkan stabilitas politik dan keamanan terganggu yang pada gilirannya akan menyebabkan stabilitas pembangunan juga terancam. Hal ini sejalan dengan pernyataan Todaro (2000) yang menjelaskan bahwa terjadinya perpindahan penduduk disebabkan oleh tingginya upah atau pendapatan yang diperoleh di daerah tujuan. Kesenjangan upah/pendapatan yang besar antara desa atau daerah dan kota mendorong penduduk desa atau daerah untuk 
datang dan mencari pekerjaan di kota. Banyaknya arus urbanisasi ini akan menimbulkan masalah dan menjadi beban bagi daerah perkotaan akibatnya akan timbul masalahmasalah sosial di Kota.

Jumlah penduduk yang menganggur di Provinsi Jambi terus berfluktasi setiap tahunnya. Jumlah pengangguran tertinggi terjadi pada tahun 2014 yaitu sebesar 79.784 jiwa dan kemudian hingga tahun 2017 jumlah pengangguran mengalami penurunan sebesar 66.757 jiwa. Sedangkan menurut Tingkat Paengangguran Terbuka (TPT) tertinggi terjadi pada tahun 2007 yaitu sebesar $6.62 \%$.

Jumlah perkembangan penduduk yang menganggur di Provinsi Jambi terus berfluktasi setiap tahunnya. Jumlah pengangguran tertinggi terjadi pada tahun 2005 yaitu sebesar 133,964 jiwa dan kemudian pada tahun 2016 penurunan sebesar 67,671 jiwa. Sedangkan menurut Tingkat Paengangguran Terbuka (TPT) tertinggi terjadi pada tahun 2005 yaitu sebesar 10,74\%. Untuk melihat lebih jelasnya jumlah pengangguran di Provinsi Jambi data dilihat pada tabel 4 dibawah ini:

Tabel 4. Tingkat Pengangguran Terbuka di Provinsi Jambi Tahun 2001-2016 (Jiwa)

\begin{tabular}{|c|c|c|c|}
\hline Tahun & Pengangguran & Angkatan Kerja & TPT (\%) \\
\hline 2001 & 60.240 & 1.073 .906 & 5,61 \\
\hline 2002 & 67.092 & 1.161 .423 & 5,78 \\
\hline 2003 & 76.659 & 1.178 .492 & 6,50 \\
\hline 2004 & 73.108 & 1.210 .568 & 6,04 \\
\hline 2005 & 133.964 & 1.247 .114 & 10,74 \\
\hline 2006 & 78.264 & 1.181 .650 & 6,62 \\
\hline 2007 & 76.090 & 1.222 .951 & 6,22 \\
\hline 2008 & 66.371 & 1.290 .854 & 5,14 \\
\hline 2009 & 73.904 & 1.334 .496 & 5,54 \\
\hline 2010 & 72.792 & 1.432 .814 & 5,08 \\
\hline 2011 & 60.169 & 1.495 .167 & 4,02 \\
\hline 2012 & 42.296 & 1.470 .920 & 2,88 \\
\hline 2013 & 70.361 & 1.452 .832 & 4,84 \\
\hline 2014 & 79.784 & 1.570882 & 5,08 \\
\hline 2015 & 70.349 & 1.620 .752 & 4,34 \\
\hline 2016 & 67.671 & 1.692 .193 & 4,00 \\
\hline Rata-Rata & & & $\mathbf{5 , 5 3}$ \\
\hline
\end{tabular}

Sumber: BPS Provinsi Jambi, 2017

Menurut Tabel 4, menjelaskan bahwa di Provinsi Jambi belum bisa menyelesaikan lapangan pekerjaan, hal ini tercermin dari masih cukup banyaknya jumlah pengangguran, meskipun terjadi penurunan rasio pengangguran di Provinsi Jambi. Jumlah pengangguran yang besar merupakan masalah bagi suatu daerah maupun negara dalam pembangunan perekonomiannya. Oleh karena itu, masalah pengangguran ini perlu ditangani dengan serius. Cara untuk mengatasi masalah pengangguran adalah dengan menyediakan lapangan kerja yang cukup untu mengejar pertambahan angkatan kerja lebih besar bagi negara berkembang terutama di Indonesia dimana pertumbuhan angkatan kerja lebih cepat dari pertumbuhan kesempatan kerja yang ada.

Pengaruh Pertumbuhan Ekonomi, Inflasi Dan Tingkat Pengangguran Terhadap Jumlah Penduduk Miskin Di Provinsi Jambi

Untuk melakukan pengujian data digunakan bantuan komputer dengan program pengolahan data statistik SPSS sehingga diperoleh hasil pada lampiran 2. Dari hasil 
pengujian (lampiran 3) diperoleh persamaan regresi sederhana sebagai berikut:

Tabel 5. Nilai-nilai Koefisien Regresi

\section{Coefficients $^{\mathrm{a}}$}

\begin{tabular}{|c|c|c|c|c|c|}
\hline \multirow[b]{2}{*}{ Model } & \multicolumn{2}{|c|}{ Unstandardized Coefficients } & \multirow{2}{*}{$\begin{array}{c}\begin{array}{c}\text { Standardized } \\
\text { Coefficients }\end{array} \\
\text { Beta }\end{array}$} & \multirow[b]{2}{*}{$\mathrm{t}$} & \multirow[b]{2}{*}{ Sig. } \\
\hline & $\mathrm{B}$ & Std. Error & & & \\
\hline $1 \quad$ (Constant) & 354520,540 & 40579,734 & & 8,736 & 0,000 \\
\hline $\mathrm{X} 1$ & $-16217,566$ & 4378,650 & $-0,671$ & $-3,704$ & 0,003 \\
\hline $\mathrm{X} 2$ & 2179,139 & 1579,945 & 0,259 & 1,379 & 0,193 \\
\hline $\mathrm{X} 3$ & 113,692 & 285,427 & 0,075 & 0,398 & 0,697 \\
\hline
\end{tabular}

a. Dependent Variable: Y

Berdasarkan Tabel 5, diatas maka dapat disusun persamaan regresi pengaruh Pertumbuhan Ekonomi $\left(\mathrm{X}_{1}\right)$, inflasi $\left(\mathrm{X}_{2}\right)$ dan pengangguran $\left(\mathrm{X}_{3}\right)$ terhadap angka kemiskinan (Y) di Provinsi Jambi sebagai berikut:

$$
\begin{aligned}
& \log Y=354.520,54-16.217 X_{1}+2179,139 X_{2}+113.692 \log X_{3}+e \\
& \text { F Test }=6,696 \\
& (0,818) \quad(-3,700) \quad(1,379) \quad(0,398) \\
& \mathbf{R}^{2} \quad=\mathbf{0 , 6 3 5}
\end{aligned}
$$

Dari persamaan regresi diatas dapat ditafsirkan bahwa setiap kenaikan pertumbuhan ekonomi di Provinsi Jambi sebesar 1\% maka Angka kemiskinan penduduk di Provinsi Jambi akan mengalami penurunan sebesar 16.217 jiwa. Hasil pengujian ini menunjukkan bahwa pertumbuhan ekonomi berdampak negatif terhadap angka kemiskinan di Provinsi Jambi.

\section{KESIMPULAN}

Persamaan regresi di atas juga menggambarkan bahwa setiap terjadi peningkatan angka inflasi sebesar 1\% maka angka kemiskinan akan mengalami peningkatan sebesar 2.179 jiwa dan setiap terjadi peningkatan angka pengangguran di Provinsi Jambi sebesar $1 \%$ maka angka kemiskinan penduduk di Provinsi Jambi akan mengalami peningkatan sebesar 113.692 jiwa. Hasil pengujian ini menunjukkan bahwa pertumbuhan ekonomi memberikan dampak negatif atau dapat mengurangi angka kemiskinan, sementara inflasi dan pengangguran memberikan pengaruh yang positif terhadap kemiskinan penduduk di Provinsi Jambi. Hal ini sangat beralasan karena dengan meningkatnya pengangguran berarti semakin rendah pendapatan masyarakat dan menyebabkan kemiskinan, begitu juga dengan inflasi, meningkatnya inflasi akan menyebabkan daya beli masyarakat akan menurun dan memberikan dampak terhadap ketidakmampuan memenuhi kebutuhan hidupnya.

\section{DAFTAR PUSTAKA}

Anonim. 2004. Kantor Kemenkesra: Jakarta.

Anonim. 2009. Indikator Kemiskinan. BPS Provinsi Jambi: Jambi.

Arsyad, Lincolin. 2001. Ekonomi Pembangunan. UPP YKPN: Yogyakarta.

Gill, R. 2003. Ekonomi Pembangunan. Terjemahan.PT. Ghalia Indonesia: Jakarta.

Ghazali, Saydam. 2011. Statistik. Alfabeta: Jakarta.

Jhingan, M.L. 2004. Ekonomi Pembangunan dan Perencanaan. Diterjemahkan oleh D.

Guritno. Rajawali Press: Jakarta.

Kadariah. 2007. Ekonomi Perencanaan. LPFE-UI: Jakarta. 
Samuelson, dan Nordhaus. 2005. Ekonomi Makro. Terjemahan. Erlangga: Jakarta. Tjiptoherijanto. 2000. Pengantar Ekonomi Pembangunan. YKPN: Yogyakarta.

Todaro, M. P. 2003. Pembangunan Ekonomi Di Dunia Ketiga. Edisi Keenam. Alih Bahasa oleh Haris Munandar. Penerbit Erlangga: Jakarta.

Wijayanto, T. 2015. Liku-Liku Kemiskinan Di Indonesia. Penerbit Liberty: Yogyakarta. Winardi. 2000. Kamus Ekonomi. Mandar Maju: Bandung.

Yudha, Okta Ryan Pranata. (2013). Pengaruh Pertumbuhan Ekonomi, Upah Minimum, Tingkat Pengangguran Terbuka Terhadap Kemiskinan di Indonesia. Jurnal Episentrum. Edisi XIX. 